\title{
ACQUISITION AND DISPOSAL POLICIES IN MUSEUMS
}

\author{
Amr Mohamed ATEF *
}

Heritage \& Museum Studies Department, Helwan University, Egypt

\begin{abstract}
Collections are the lifeblood of a museum, and the basic components of a museum's very existence. Every museum should have a written collecting policy a guideline; these guidelines are offered as a checklist for the museum interested in drafting or revising a collection management policy. This guideline formally agreed by its governing body. This written policy will be part of the museum's collections management policy and its forward plan that sets out the museum's intentions for all aspects of its work. This essay discusses acquisition policies, sources, and procedures. In addition to deal with why does museum get DE accession or disposal it collection and what are their alternatives or option.

Keywords

Acquisition - Museum - Policy - Collection - Management-Policy.
\end{abstract}

\section{Introduction}

Acquiring collection one of most important pillars of collection management that each museum strives to apply according to international standard. Ladkin (2004) conducted that there are three keys inter-related elements of collections management:

Registration of collections: provides baseline institutional accountability for the many and various objects, artefacts, specimens, samples, and documents that the museum holds in trust for current and future generations of humanity.

Preservation of collections: is an important, active aspect of collections management that underlies all other museum activities.

Providing controlled access: to collections through exhibit or research fulfils the museum's mission to educate and interpret while protecting collections at the same time.

According to Fahy (1995) Acquisition policy should support the museum's mission. It's important to aware that Collections advance the museum's mission while serving the public. Because collections are held in trust for the public and are made accessible for the public's benefit, the public expects museums to maintain the highest legal, ethical and professional standards. To demonstrate these standards, museums establish policies to support its mission and operations and to guide decision-making. Policies give the governing authority, staff and public the opportunity to learn about standards and help the museum fulfill its responsibilities as a steward of collections (Developing a Collections Management Policy, 2016).

*Corresponding author: museumstudies@helwan.edu.eg 


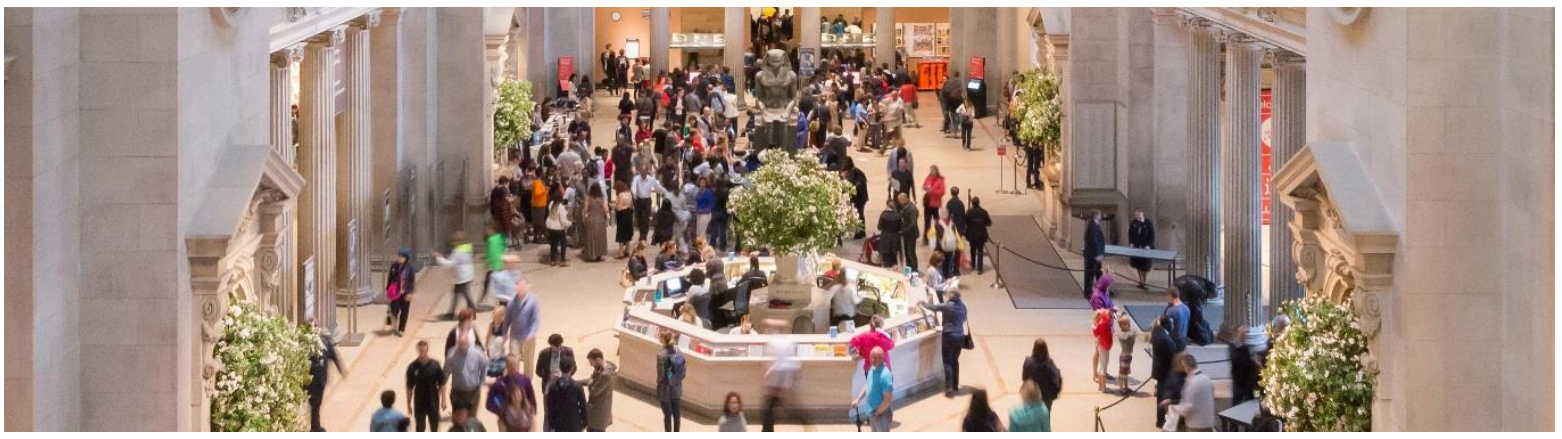

Fig (1) Metropolitan museum of Art

\section{Acquisition and Disposal Procedures}

\section{Acquisition and accessioning}

Acquision is the process of obtaining on objects or collections for museum, Objects can be acquired in many ways, such as from fieldwork, as a donation or bequest, or as a transfer from another institution (Ladkin, 2004, p. 17-30).

Every museum should include in its collecting policy the principles set out in ICOM's Code of Ethics for Museums some of the most important are: (Ambrose and Paine, 2006, p.137).

- Objects or specimens will be acquired only if the museum is satisfied it can obtain valid title.

- The museum will not acquire objects where their recovery may have involved the unauthorized, unscientific or intentional destruction or damage of monuments, archaeological or geological sites, or species and natural habitats.

- Collections of human remains and material of sacred significance will be acquired only if they can be housed securely and cared for respectfully.

- The museums will not acquire biological or geological specimens that have been collected, sold or otherwise transferred in contravention of local, national, regional or international law or treaty relating to wildlife protection or natural history conservation.

- Every effort must be made before acquisition to ensure that the object has not been illegally transferred from another country.

Accessioning is the formal acceptance of an object or collection, recording it into the register of a museum and incorporating it into the museum's collections. Each object, or group of objects, to be kept by the museum (whether gift, purchase, bequest or long loan) is entered in the accessions register (Malaro, 2005, p.11-29).

The word accession may be used to denote an object acquired by a museum for its 
permanent collection or the act of recording/processing an addition to the permanent collection by assigning a unique number that allow the museum to connect an object to it documentation. All accessioned objects are acquired but not all acquisitions are meant to be accessioned, it is not necessary for a museum to accession every object that it acquire. An acquisition is made by museum when title of an object is transferred and the museum becomes the owner (Buck and Gilmore, 1998, p.157). The museum must ensure that each accession not only enhances or strengthens the museum's collection but can be properly cared for, stored and used. (Developing a Collections Management Policy, 2016).

\section{Acquisitions sources}

Objects may be added to collections by means of gifts or donations, bequests, purchases, exchanges, fieldwork acquisitions or any other transaction by which title to the objects passes to the museum.

\section{Gifts / donations}

Gifts or donations one of most acquisition resources which each museum seeking to obtain its new collection through its. Gifts can be outright or fractional or promised. In other case may be unrestricted or made with some restrictions (Buck and Gilmore, 1998, p.157).

\section{Restricted and Unrestricted gifts / donations}

Buck and Gilmore (1998) mentioned that unrestricted gifts are always preferred, because it allows the museum to use the collections according to written museum's policy. Although there will be some circumstances in which the objects are such important addition to a collection that some restrictions are

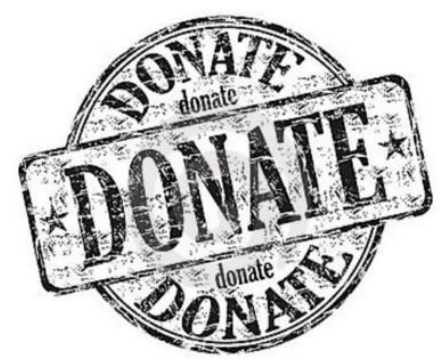
acceptable. The acceptance of unrestricted gifts is depending on the donors and the nature of the restrictions requested.one other hand restricted gifts are difficult require more negotiation to persuade the donors to accept all museums policy in same time providing some satisfaction. For example, some donor's requests to display his collections in permanent exhibition, or to keep it's together in same showcases.

\section{Promised gifts}

Promised gifts may be made by a donor in the form of a letter expressing the donor's intent to give a specific object to the museum of some future time. Museum may wish to encourage the donor to include the gift to museum in his or her will to ensure that the donor's promise is carried out if the donor is unable to make the gift during his or her lifetime. A promised gift may be in the custody of the museum, it should be treated as a loan and should follow all acquisition procedures. (Buck and Gilmore, 1998, p.158). 


\section{Fractional gifts}

Fractional gifts are generally made for tax reasons, they are most likely to be used by donors who are less concerned with obtaining tax deductions from the donation. It may be given by a donor who wants to ultimately provide a piece of art to a museum, but who is not ready to fully part with the item presently. The donor will still be able to enjoy a charitable income tax deduction, though the percentage deduction is open to more stringent regulations.

The museum shouldn't accept a fractional gift unless the donor agrees to give the remaining portion to museum within a set period. Because museum want to control its collections and doesn't want to find itself in position where only a forced sale of those objects. A fractional gift should be treated as outright gifts and all acquisition process should be applied (Buck and Gilmore, 1998, p.158).

\section{Bequests}

A bequest is the transfer of property to the museum under the term of a deceased person's will. It is important to have on record, as evidence of the transfer of title, a copy of the provision of the will that concerns the bequest to the museum and a copy of the final receipt the museum signs accepting the bequest. Museum are usually notified of a bequest by the executor (legal representative) of the estate. It is important to deal with the official representative of an estate. According to Morris (2001) two problems arise regarding bequests in respect of which it is specified:

a. The objects donated or bequeathed must be exhibited.

b. The series of objects bequeathed must be exhibited as an indissoluble whole.

The obligation to exhibit permanently runs counter to modern museum principles, about both presentation and preservation, in the case of objects which may deteriorate if exposed to the light for long periods. Compulsory 'group display' of objects bequeathed is usually an obstacle to the logical arrangement of exhibits. For this reason, certain countries offer is even systematically refused if such conditions apply. However, the disadvantages of this policy must be weighed in the case of outstanding masterpieces. (Schommer, 1960, p.28-51)

\section{purchase}

Museums can purchase its collections by many ways, at auction and from or through dealers or directly from individuals. By bargain sale, Museums negotiated a price with the vendors to get the best price, and donor offers an object to museum at substantially lower than fair market value with the intention of benefiting the museum by virtue of reduced price. After purchasing object, it is important that the museum have a bill of sale and proof of payment and such document should be part of acquisition file (Morris, 2001, p. 3.37). 


\section{Exchanges}

Exchange in fact are a form of purchase, but the different is the payment not in currency but is in the same kind. Some museums have duplicate objects in the same time has a shortage of some of the other objects, which are gap in the display. Museums try to exchange these objects with other museums or academic research to complete the exhibition scenario. The term of an exchange may be permanent or temporary, it should be set forth in writing and museum for its records should be establish the fairness of exchange by means of appraisals and other expert opinions. The written agreement concerning the exchange and all relevant documents concerning the justification for the exchange and execution for the exchange should be a part of acquisition file. (Buck and Gilmore, 1998, p.159).

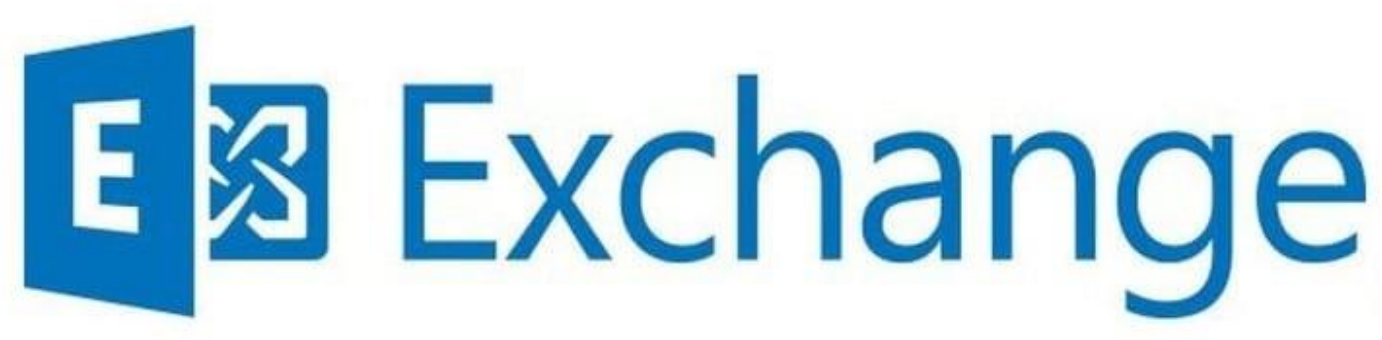

\section{Field collections}

Museums like many academic, research institutions have a responsibility to make information about their collections available. Collections research plays a vital role in museums; it provides an access to collections. They are extremely important in spreading awareness about the range of museum collections, enhancing individual in-house knowledge and expertise of objects and encouraging wider research into collections. There is difference between museums and academic institutions is that the museum publicizes the results of its research through public exhibitions and displays. And the series of scientific and scholarly monographs which have been published by various museums are similar to those published by universities on the same type of work. Research on museum' collections and publications of findings allows museums to address their education and interpretation mission. There are many academic standers that each museum should follow its. It necessary that all museum research is legal and ethical in accordance with academic standers and support the mission of museum. (Ladkin, 2004, p. 17-30).

Museums form a link with university expertise, with archaeologists and historians involved with artifacts, with geologists and natural historians. It also is or should be a transmitter and mediator of knowledge and expertise to other museums and museum staff, in fulfilment of an important postrol role which relates to them and to heritage in general, as a 
part of broad educational thrust. there is an opportunity to take initiatives to fill gaps in the processes of research that institutes of higher learning are increasingly forced to ignore, especially in relation to the collections that give museums a unique cultural and educational role (Fenton, 2005, p. 224-232).

In recent years, the public as well as the museum community have had their interest in ethnographic material awakened for a variety of reasons. Resources are being sought for educational programmes more suited to a multicultural society. Concern for preservation of world heritage has focused attention on ethnographic collections. Ethnographic material is referred to as material cultural or tribal art" the range of objects is extremely large and includes everyday items such as carved spoons, stools, weapons, ceramic, costume and sculpture. These collections reflect the history both good and bad of people, some collections have been developed in a systematic way, documented by scholars while other have resulted from occasional donations to museums from different families or business travels (Kwasrik, 2005, p. 217). Most ethnographic museums have such programmes, and there are many small or local museums whose staff also engage in research. Museums have attempts to take a very particular approach to present scholarship to their public as way of allowing the public to discover and possess their collection (Gregor, 2005, p. 222-226). Their curators may conduct research independently or in cooperation with members of larger museums, universities, learned societies, etc. Such co-operative work is also advantageous to larger museums as a means of obtaining local co-operation and the use of local facilities. Curatorial staff should have academic training to give them the necessary background for the execution of their duties, and particularly for research work. Academic training is, in fact, the minimal requirement, for successful research projects depend in the final analysis upon the initiative and interest of the researcher; the human element is the most important.

In many respects, research is a process building on the curator's personal interests and training, a constant reasoned accumulation of knowledge during experience a transformation of raw data in archives computers and notebooks into vehicles of through about the collections and their significance in terms of development of the physical world and of community in general. Museum publications carried on by certain museums is evidenced by their 'papers', 'series', 'quarterlies' and other types of scholarly monographs and journals. These publications have a wide circulation among libraries, universities, museums and professional people whose interests they serve. Museum staff members also publish articles in professional journals or have books published by commercial printers. Reports on research work, or the results of a museum expedition often appear too, in the popular press-usually prepared by those 
responsible. Some museums publish in their monthly magazines 'popular' scientific articles, summarizing the work being done by their staff or by other allied institutions. Thus, the contributions of museums to research are publicized not only in the professional journals but are made available to the public. (Fenton, 2005, p. 224-232).

\section{Field collecting}

Museums in general acquires its collections through many different acquisition ways, it interests to collect everything related with people's cultural life. In recent years many museums carry out many scientific trips to explore new cultures in different countries like national museum of ethnology. Those museums providing all technical and financial support, funds, publish their research, and exhibits its collections. In this case, the curators using all anthropology tools in field study, like interview, observation and observatory participation to identify what is behind cultural attitudes and object. In addition, collect more deeply information about intangible heritage of those people. (Ladkin, 2004, p. 17-30).

\section{In - house research}

Museums like academic institutions, interest to publish its researches and unique information, which carried out by curators. Researching is the main task for every curator to provide more information about exhibitions and its collections. They responsible for collecting all details about every object within museums from sources and references. Many museums publish their scientific achievement in publications periodically, monthly, annual and quarter. So, in some museum curators having master degree and PHD. And the progress and development of any museum is measured by the scientific production of their curators and other staff. It's very important that research by museum staff should relate to the museum's mission and scope and in accordance with academic standard (Ladkin, 2004, p. 17-30).

\section{Visiting scholars}

Museums have good opportunities to create joint research programmes with other museums or allied institutions known to be collecting or to hold collections in the same subject areas. Collections research projects of this type can often lead to improved understanding and awareness of the importance of holdings, throw new light on collections through documentary research and lead to joint publications, exhibitions, associated collecting, and research projects. Some museums did not have specialist enough to cover all disciplines related with museum field so they recruit many museum specialists to fill gaps in some point out of specialization. This partnership allows filling gaps and supporting research in both museums. Some museums cooperate with them to create exhibitions and mutual publication. (Ladkin, 2004, p. 17-30). 


\section{loans}

Loans are the temporary removal or reassignment of an object or collection from its normal ownership or location. They help museums share information with each other and the communities they serve. They are made between museums or from private individuals to museums. Each museum should have a written loan policy that include on both incoming and outgoing loans. The most common type of loans is internal exhibitions loans which objects are borrowed for specific period for a specific purpose. There are Loans for traveling exhibitions (touring exhibitions). It usually between different countries' museums. Exchange loans, may be for the mutual benefit of the museums, some museums request loan to fill the resulting gap in its permanent exhibition. In some case, the unsolicited objects are often received for a loan, the sender should be notified that the unsolicited parcel will be returned at the sender's expense in the same manner that it was packed and shipped. (Buck and Gilmore, 1998, p.178).

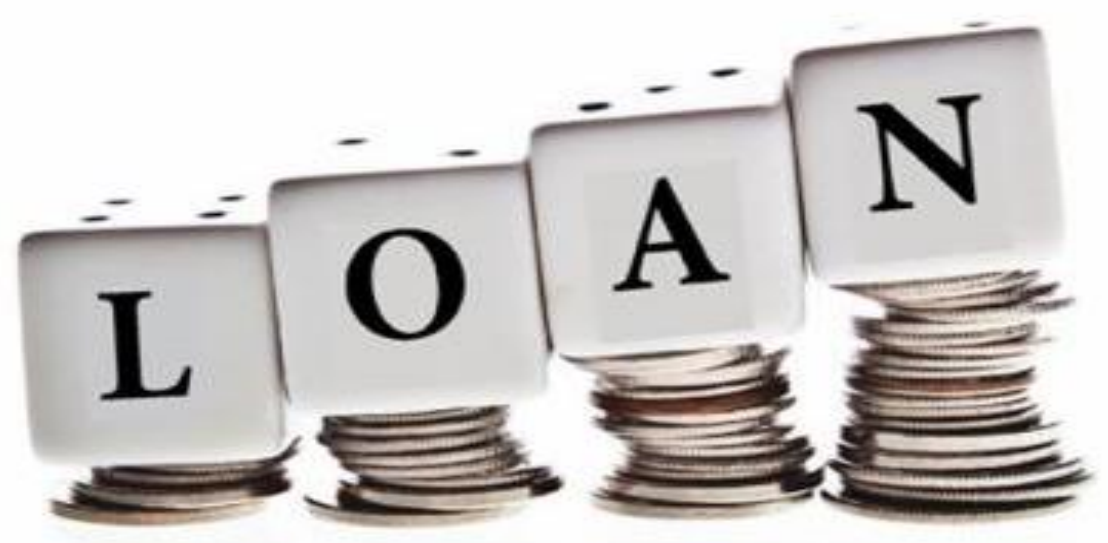

Loans to other public or educational institutions allow museums to share their collections and enhance and support exhibitions and research projects that fulfil their educational goals.

\section{Incoming loan}

An incoming loan is borrowed by the museum from a lender, - its owner or other normal holder, which can be another museum or an individual. It involves a change of location of objects and collections but not of title (legal ownership). There is customary protocol for requesting loans that the director, curator and registrar of borrowing institution to send the prospective lender a detailed letter describing the purpose of exhibition and should contain the following key information such as; (Schommer, 1960, p.28-51).

- $\quad$ exhibition title and its purposes

- $\quad$ length of loan period

- $\quad$ locations of exhibition with dates

The borrower's responsibility to pay for all expenses incurred in preparing a loan, packing, 
shipping and insurance.

\section{Outgoing loan}

An outgoing loan is the opposite; it involves lending out to another museum's collections. Many museums policy prohibit outgoing loans to individuals or private corporations, and even without formal restrictions are usually discouraged because an individual may not be able to care for and keep an item from a collection safe. Some museums or other institution request for a loan, the curatorial committee should approve in general and indicate the availability of loan based on any unannounced projects he or she may know about. And both the conservator and registrar examines the conditions of the objects to be loaned. Then the registrar also checks any legal restrictions customs restrictions. In evaluating the objects condition, there are some consideration: (Buck and Gilmore, 1998, p.177).

- Are the objects able to resist of travel and additional handling?

- Is the object too fragile to be displayed safely?

- Should special restriction be placed on light levels or general environment exposure?

For these reasons it is very important that requests for loans are considered carefully. It is very important that loans are fully documented so either borrower or lender understand in detail all the conditions of the loan. And can issue the final loan agreement, it is usually done by the borrower, if the lender and borrower both have loan contracts, they can sign each other form (Schommer, 1960, p.28-51).

As following, some considerations should be observed before an outgoing loan process:

- To ensure that objects of loans is not prohibited.

- To ensure that the objects condition very well according to curator's opinion and is not such as to prevent its transport.

- to obtain the consignee's preliminary agreement after checking these points, the purposes of loan, the dates of dispatch and return, the technical and financial procedures for packing and insurance and transportation.

\section{DE accessioning and disposals}

$\mathrm{DE}$ accessioning is the opposite of accessioning. It is the process of the permanently removing of an object from a museum's collections and records. There are many reasons for DE accessioning an object, from refining the focus of the collection, to repatriation of objects, to removal of unsalvageable, deteriorated, infested objects. Because museums fulfil a public trust, DE accessioning can be controversial. It is important that the museum understand the legal and ethical implications of DE accessioning and write a policy that helps the museum be transparent and accountable with the public. So Many museums are prohibited from DE 
accessioning by national laws or in their own governing charter or institutional policies. However, every museum should have a process for deciding on and recording legally permissible disposals. (Abdel-Magueid, 2015).

\section{Alternatives to deaccession}

There are some methods to benefits from deaccessioned objects such as (Ladkin, 2004, p. 1730):

- Long-term loan: Many museums lend deaccessioned collection for educational purposes or exhibitions display for an extended period, usually more years for public display or study by other qualified museums or educational organizations.

- Shared ownership: Some museums have elected to enter into agreement with other museums for shared ownership of specific deaccessioned objects according to community interest.

- Collaboration: Some museums preferred to collaborate with other museums by exchange deaccessioned objects to fill gap in exhibitions, sharing collections and exhibition that like a long-term loan arrangement.

Disposal is the act of physically removing deaccessioned collections objects from the museum and relocating them elsewhere. Depending on applicable law, disposal options may include transfer to another museum or similar institution for educational purposes, physical destruction of deteriorated objects, and restitution to another group or people. (Ladkin, 2004, p. 17-30).

There are reasons why a museum might want to get rid of an object, and some of these are good reasons and some are bad: (Ambrose and Paine, 2006, p.138).

- the object has decayed so badly that it is now quite useless

- It has been discovered to be a fake, or was wrongly identified.

- It does not fit into the museum's collecting policy.

- To sell it, and buy a better example.

- To make an exchange with another museum.

- The museum already has many examples of this object.

- The museum is ordered by state authorities to do so.

- To return the object to its country or people or region of origin.

\section{Disposal options}

The following are common option for disposal of deaccessioned material: (Buck and Gilmore, 1998, p.169).

1. Donation of the objects to another museums, libraries and archives for educational 
purposes.

2. Exchange with other museums or non-profit which be made in such a way that there is relatively equal value of items involved.

3. Using it within educational and research programs like scientific study, school programs, hands-on demonstrations, exhibition props and conservation research.

4. Physical destruction, because some objects may have deteriorated due natural disaster, vandalism, accident. So, items may be considered dangers such as those objects containing drugs, chemicals, explosives, or asbestos and should be disposed of.

5. Selling objects by private sale in some case where the public auction is not possible or practical.

6. Returning to donor when the museum has failed to meet the requirements or conditions of the original gifts or bequest.

7. Making public auction when there is a need to generate funds to improve the prospect for future collecting for example when the Northampton museum decided to sell Skhemka statue to improve the museum's collection.

8. Contracting with the auction houses, which most of them have standard contract, so the museum should carefully review all documents, sharing it with legal counsel.

In conclusion, it can be said that although many museum collections are large, complicated and very different in contents, they share in similar characteristics that all representative of natural, cultural and scientific heritage. All museums strive to apply the best professional practice in which museum collections are assembled, organized, researched, interpreted, and preserved, with the aim of ensuring that the collections are managed and cared for properly. Finally, the process of creating and implementing a collection policy is far more important and beneficial to the museum than the actual policy itself. The policy may seem like the result, but the result is a broad understanding of ethics and procedures, which influences how the museum acquire.

\section{References:}

- $\quad$ Ambrose, T., \& Paine, C. (2006). Museum basics (Second ed.). London: Routledge.

- $\quad$ Buck, R. A., \& Gilmore, J. A. (1998). The new museum registration methods. Washington, DC: American Association of Museums.

- Developing a Collections Management Policy. (n.d.). Retrieved April 22, 2016, from http://www.aam-us.org/docs/default-source/continuum/developing-a-cmpfinal.pdf?sfvrsn=4 
- $\quad$ Fahy, A. (1995). Collections management. London: Routledge.

- Fenton, A. (2005). Collections research: local, national and international perspectives. In Collection Management (pp. 224-232). London: Routledge.

- $\quad$ Gregor, M, N. (2005). Scholarship and the public. In Collection Management (pp. 222226). London: Routledge.

- Kwasrik, E. (2005). Foreign ethnographic collections research programme. In Collection Management (pp. 217-218). London: Routledge.

- $\quad$ Ladkin, N. (2004). Collections management. Running Museum, a Practical Handbook, 1730.

- Magueid, O. A. (2015, February 22). Collection management. Lecture presented at Museology course in Faculty of tourism and hotels management, Cairo.

- $\quad$ Malaro, M. (2005). Collection management policies. In Collection Management (pp. 1129). London: Routledge.

- Morris, P. (2001). Museum collections Management handbook (Vol II). California: California State Park.

- Schommer, P. (1960). Administration of museums. In The organization of museums: Practical advice (pp. 28-51). Paris: Unisco.

- Ghada Majid Muhammad JALALI, CULTURAL INDUSTRIES AND THEIR RELATIONSHIPS WITH PRESERVING THE IDENTITY, International Journal of Multidisciplinary Studies in Heritage Research, Vol. 1, No. 1, 2018, pp. 11-14.

Received: July 5, 2018

Accepted: September 9, 2018 